\title{
Disability In Higher Education: Redefining Mainstreaming
}

Jeanne L. Higbee, University of Minnesota, Twin Cities, USA

Rachel E. Katz, University of Minnesota, Twin Cities, USA

Jennifer L. Schultz, Metropolitan State University, MN, USA

\begin{abstract}
This paper addresses key issues in mainstreaming and inclusion for postsecondary students with disabilities and the subtle ways in which students and educators with disabilities can be marginalized. The paper also considers the exclusion of disability in conversations about diversity in higher education.
\end{abstract}

Keywords: Disability, mainstreaming, universal design, universal instructional design, access

\section{INTRODUCTION}

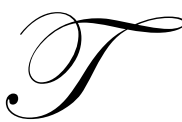

he population of students pursuing higher education is becoming increasingly diverse (Crissman Ishler, 2005). Throughout the world, educators are striving to enhance educational opportunity for students from historically underserved populations (David, in press; Ferrier \& Heagney, 2008; Higbee, 2009). A growing body of research indicates that being part of a diverse educational community can enhance growth and development in important skills like leadership, critical thinking, and cross-cultural communication (Antonio, 2001; Barron, Pieper, Lee, Nantharath, Higbee, \& Schultz, 2007; Blimling, 2001; Gurin Dey, Hurtado, \& Gurin, 2002; Maruyama, Nirebim, Gudeman, \& Marin, 2000; Milem \& Hakuta, 2000; Pascarella, Palmer, Moye, \& Pierson, 2001; Smith \& Schonfeld, 2000; Terenzini, Cabrera, Colbeck, Bjorklund, \& Parent, 2001; Zuñiga, 2003). However, this research has focused primarily on racial and ethnic diversity; in conversations about diversity in higher education, disability is seldom mentioned (McCune, 2001).

The purpose of this paper is to address disability and mainstreaming in postsecondary education, with the focus going beyond mainstreaming students with disabilities in the classroom to discussion of how the topic of disability is marginalized in other ways as well, even in inclusive conversations about diversity. It is important to provide a context for reflection on why this matters, why it should be a critical issue of concern in postsecondary education today.

\section{BACKGROUND}

Approximately 1 in 5 people in the U.S. has a disability, while 1 in 10 has been diagnosed with a severe disability (U.S. Department of Commerce, 1997). With respect to an individual, the Americans with Disabilities Act of 1990 (ADA), as amended in 2008, defines the term "disability" as:

a physical or mental impairment that substantially limits one or more major life activities of such individual. . . major life activities include, but are not limited to, caring for oneself, performing manual tasks, seeing, hearing, eating, sleeping, walking, standing, lifting, bending, speaking, breathing, learning, reading, concentrating, thinking, communicating, and working. . . . a major life activity also includes the operation of a major bodily function, including but not limited to, functions of the immune system, normal cell growth, digestive, bowel, bladder, neurological, brain, respiratory, circulatory, endocrine, and reproductive functions. (U.S. Department of Justice, 2009) 
A person with a severe disability is defined as "a person who is unable to perform one or more activities, or who uses an assistive device to get around, or who needs assistance from another person to perform basic activities" (U.S. Department of Commerce).

In the U.S. students with disabilities are attending college in greater numbers than ever before. National Center for Education Statistics (NCES) data from the 2003-2004 academic year indicated that $11.3 \%$ of college students in the U.S. reported having a disability; of these $3.8 \%$ had visual disabilities, $5.0 \%$ had hearing impairments, $0.4 \%$ had speech impairments, $25.4 \%$ had orthopedic disabilities, $7.5 \%$ had learning disabilities, 11.0\% had Attention Deficit Disorder (ADD), 21.9\% had a mental illness or depression, $17.3 \%$ had health impairments, and 7.8\% indicated "other" (Horn, Nevill, \& Griffin, 2006). These figures should be considered underestimates because many students with disabilities choose not to self-disclose, and would thus not be part of those "counted" by NCES. Despite recent legislation, students with disabilities continue to experience both overt and more subtle forms of discrimination.

Although learning is among the major life activities included in the ADA's definition of what constitutes disability, students with cognitive disabilities like learning disabilities, Attention Deficit Hyperactivity Disorder (ADHD), and Autism spectrum disorders sometimes experience doubt on the part of faculty regarding the legitimacy of the disability or the fairness of providing academic accommodations, despite having provided appropriate documentation (Hill, 1996; Kalivoda, 2003; Kalivoda \& Higbee, 1998; Williams \& Ceci, 1999). This lack of acceptance for students with "hidden" disabilities can result in a decision to "fake it" (Lee \& Jackson, 1992) - to attempt to make it on their own without using available supports or seeking appropriate academic accommodations - rather than disclose a disability (Alexandrin, Schreiber, \& Henry, 2008; Uncertain welcome, 2002). Students with visibly apparent disabilities like visual and mobility impairments also continue to be treated as "deficient" rather than merely "different": "Like students of color, those who can be identified at a glance as physically different experience assumptions about inferior intellectual capacity" (McCune, 2001, p. 9).

Students with disabilities continue to be segregated or excluded throughout the college experience; institutions and individual educators still need to pursue more inclusive approaches to all aspects of college life, from orientation (Higbee \& Kalivoda, 2008) to residence life (Wisbey \& Kalivoda, 2008) and other social situations (Tregoning, 2009b), as well as in the classroom (Hatch, Ghere, \& Jirik, 2008; Higbee, Chung, \& Hsu, 2004). Although similar forms of segregation are no longer tolerated on the basis of race or ethnicity, seating for students using wheel chairs is often limited to the rear of the classroom. Like students who are not native speakers of English, students who communicate via interpreter or speech synthesizer find themselves excluded from class discussion if the faculty member does not control the pace of the conversation so that their voices can be heard, and may also have to deal with the discomfort of other students who have difficulty understanding and are not sure how to respond (Hatch et al.). Furthermore, like students for whom English is a "foreign language", students who use American sign language (ASL) face additional challenges because ASL is not bound by the same conventions as spoken and written English (Kalivoda, Higbee, \& Brenner, 1997).

Thus, although students with disabilities are "mainstreamed" in U.S. postsecondary institutions and are attending in increasing numbers, many are still not fully integrated in college life. In 2010 we celebrate the 20th anniversary of the passage of the ADA; this is an appropriate time to reexamine institutional, curricular, and pedagogical practices that can serve to enhance or inhibit the full participation of students with disabilities. Although the ADA is specific to the U.S., similar laws have been enacted in other countries (e.g., the United Kingdom's Disability Discrimination Acts of 1995 and 2005, Directgov, n.d.), and the United Nations (UN) has established an international civil rights convention on the rights of people with disabilities (UN Enable, n.d.). Thus, many nations are prioritizing educational access for people with disabilities, but now it is time to look beyond mere access and examine whether students with disabilities are being given equitable opportunities for success in postsecondary education.

\section{MAINSTREAMING IN EDUCATION IN THE U.S.}

"Mainstreaming", or "integration of special students", is commonly defined as "the practice of educating students with special needs in regular classes during specific time periods based on their skills" (Encarta® World English Dictionary, 2009). Prior to the passage of the Education for All Handicapped Children Act (EHA) in 1975, 
one in five children in kindergarten through secondary (K-12) education in the U.S. attended public school, but were frequently segregated from other students and did not necessarily receive the supports they needed to be successful. Meanwhile, many children with disabilities were segregated in state institutions. The EHA, later renamed the Individuals with Disabilities Education Act (IDEA), mandated a process for identifying, documenting, and accommodating students with disabilities that is centralized within the child's school and includes the child, family, and school in the development of an Individualized Education Plan (IEP). Children are then mainstreamed (i.e., not segregated in separate special education classrooms) to the extent or for as much of the day as developmentally possible.

\section{Mainstreaming in K-12 Education}

Although there are arguments both in favor and against mainstreaming in K-12 education (Haas, 1997), for many students, including those with hidden social and cognitive disabilities, mainstreaming is critical to the growth of the child. To demonstrate this phenomenon, we will use the spectrum of autism disorders as an example. According to Autism Speaks, a Web site that provides information and resources for families, the rate of diagnosis of children with autism is growing faster than any other serious developmental disability in the U.S., and particularly among boys, who are four times more likely than girls to have autism (Facts About Autism, 2009). Autism affects "1 in 91 children and 1 in 58 boys", making it more common than pediatric cancer, diabetes, and AIDS combined (Facts About Autism). Autism is a communication and social disorder that directly affects how people with autism interact with others. Many people with autism have the desire to fit in and socialize with other people, but lack the necessary skills to do so. Thus, it becomes vital for these individuals to gain an understanding of everyday social norms and experience normal social interactions (Haas, 1993). Placing students with autism into general education classrooms provides these students with the opportunity to observe and experience these interactions first hand (Mesibov \& Shea, 1996). When separating these students from the students in the general education classroom and placing them in special education classes, or classes for children with autism only, schools deprive them of the natural social interactions that so many of them crave (Haas, 1997). People learn a vast amount of their knowledge though experience and interaction with their peers. How to react in different social situations, how to respond to social cues like a person's body language, and the intonation in his or her voice, are all skills that must be fostered through experience in a social environment (Haas, 1993). Children who have the opportunity to develop these skills will then be more likely to acquire the necessary skills to become job holders and tax payers (Mesibov \& Shea). Furthermore, research indicates that children with autism who are mainstreamed tend to have higher academic achievement, higher self-esteem, and a greater probability of attending college (Haas, 1993).

Mainstreaming in K-12 education can be dually beneficial for both students with autism and general education students. It is important for other children to interact with people with disabilities in order to gain deeper understanding of how a disability affects their lives (Haas, 1997) and to foster feelings of empathy and the belief that people with disabilities are not "abnormal." Learning in the same classroom as a child with autism, the general education students will become more accepting of individual differences, making it easier for the children with disabilities to assimilate into the school environment as well as society as a whole. An additional benefit is that it is likely that the general education students will feel significantly more comfortable in dealing with individuals with autism, or any disability for that matter, later in life.

\section{Disclosure and Mainstreaming in Postsecondary Education Settings}

Similarly, we would hope that all students benefit from the mainstreaming of students with disabilities in higher education. However, no one has undertaken research related to this aspect of diversity to mirror the research related to the benefits of racial and ethnic diversity. Meanwhile, postsecondary students with disabilities also have the right to choose to keep their disability confidential - to decide on an individual basis when and with whom to disclose - so it would be much more difficult to conduct a research project of this nature; the researcher would not know the identities of the students in the sample who have disabilities and have chosen not to disclose them.

Disclosure creates other issues as well. One of the problems with many of the academic accommodations traditionally provided for postsecondary students with cognitive disabilities or psychiatric disorders, depending upon the diagnosis, is that the act of providing them can both segregate students and result in a de facto breach of their 
confidentiality. For example, many students with disabilities qualify for such accommodations as note takers, receiving classroom materials in advance, extended time on tests, and/or a less distracting testing environmentaccommodations that can either identify them and give the appearance of "special benefits" which can be misconstrued by student peers and faculty alike as providing an unfair advantage (Kalivoda, 2003; Williams \& Ceci, 1999) or segregate them from their peers. In the Digital Age more of these accommodations can be provided electronically so that in the classroom the instructor may no longer need to provide handouts to one student that are not being provided to all, or may be able to arrange for a peer note taker without even the note taker knowing who will receive the notes.

One of the greatest challenges for postsecondary students with disabilities in the U.S. is that they go from a centralized support system in K-12 education that provides an IEP developed with input from multiple stakeholders (e.g., parents, teachers, therapists and other specialists) around the student's strengths and challenges, to a situation in which they must advocate for themselves through each step of the process, from documenting the disability to seeking accommodations (Kalivoda \& Higbee, 2008). Furthermore, this process can involve interactions with myriad offices and individuals, including separate conversations with each instructor every academic term. When a disability such as autism or a psychiatric disorder can interfere with communication or affect self-esteem, the student may choose not to disclose a disability at all or delay disclosure until absolutely necessary rather than seek needed accommodations (Alexandrin et al., 2008; Lee \& Jackson, 1992; Uncertain welcome, 2002). If a student chooses not to disclose a disability during the college admissions process, that student may never receive any further information about how to navigate the institution's policies and procedures for accommodations, which can vary greatly from one institution to the next. Educators who are concerned about inclusion have turned to universal design (Bowe, 2000; The Center for Universal Design, 1997) and its applications to instructional design for possible solutions that eliminate the need to segregate students with disabilities when possible.

\section{UNIVERSAL DESIGN AND UNIVERSAL ACCESS}

After the passage of the Americans with Disabilities Act (ADA) in 1990, postsecondary institutions in the U.S. were challenged to make their campuses physically accessible. Architects became proactive in their response and proposed universal design (UD) principles to encourage consideration of all potential future users of a building or facility when designing the space (The Center for Universal Design, 1997, 2007). The "universal" in UD is not intended to imply that one size fits all. Instead, it refers to universal access through design efforts that embrace a wide range of individual perspectives. Article 2 of the UN Convention on the Rights and Dignity of Persons with Disabilities (UN Enable, n.d.) provides the following definition of UD:

Universal design means the design of products, environments, programmes and services to be usable by all people, to the greatest extent possible, without the need for adaptation or specialized design. "Universal design" shall not exclude assistive devices for particular groups of persons with disabilities where this is needed.

Proponents of UD assert that when providing an architectural feature - or educational service or program, for that matter - to ensure accessibility and inclusion for one population, we are likely to benefit other prospective occupants or participants as well. For example, many people make use of curb cuts, automatic doors, and other features initially created for use by people with disabilities.

The ADA requires not only physical spaces to be accessible, but for courses, curricula, and academic programs to be accessible as well for students with all types of documented disabilities. Educators who recognized the promise of UD have developed three models for adapting it to educational settings: universal design for learning (UDL; Center for Applied Special Technology, n.d.; Rose, 2001; Rose \& Meyer, 2000), universal design for instruction (UDI; Scott, McGuire, \& Shaw, 2001, 2003), and universal instructional design (UID; Silver, Bourke, \& Strehorn, 1998). Although different in approach and scope, the implementation of these models enhances educational opportunity for all (Burgstahler \& Cory, 2008; Goff \& Higbee, 2008a, 2008b; Higbee \& Goff, 2008). Some students with disabilities will still require structural accommodations such as screen readers and other assistive technologies (Kalivoda, Totty, \& Higbee, 2009; Knox, Higbee, Kalivoda, \& Totty, 2000), appropriate seating arrangements, captioning, or less distracting test environments. However, implementation of models like UID can reduce or eliminate some situations that have resulted in the segregation of students with disabilities in the 
past. For example, extended time for taking tests is a relatively common accommodation for some types of disabilities. In curricula, programs, and courses for which speed is not essential to performing a task well, eliminating time constraints can enable many students to demonstrate their knowledge more effectively. Thus, when testing experiences are set up to provide all students with the equivalent of extended time, many students, including those with test anxiety and students who are not native speakers of the language in which the course is being taught, may perform at a level more consistent with their learning. Meanwhile, some students with disabilities will be able to remain in the classroom rather than being segregated in a separate testing environment.

Two of the guiding principles of UID, based on the work of Chickering \& Gamson (1987), involve using multiple teaching methods to accommodate students' wide range of preferred learning styles and ways of knowing, and then to create a variety of mechanisms for students to demonstrate their knowledge (Higbee, Chung, \& Hsu, 2004). These principles reflect Barr and Tagg's (1995) paradigm shift to focus on learning rather than teaching, enhancing student engagement and providing students with opportunities to learn from one another as well. As postsecondary student populations become more diverse, it is critical to recognize the contributions of multicultural perspectives in the learning process; everyone benefits.

\section{THE MARGINALIZATION OF DISABILITY IN THE DIVERSITY MIX}

Although recent efforts in higher education to promote inclusion for students with disabilities have benefited others as well, disability continues to be excluded from many conversations about social justice in postsecondary education (McCune, 2001), and the approach of many educational institutions to disability issues remains grounded in medical or environmental models of disability that ignore the role of social constructions in defining disability (Evans, 2008). Faculty and staff (Higbee \& Mitchell, 2009), as well as students, continue to feel the effects of subtle forms of discrimination. Tregoning (2009b) wrote about the "unconscious assumptions" (p. 184) people without disabilities may make regarding their professional colleagues with disabilities, including an absence of significant relationships or a social life. These assumptions can have a subtle impact on interpersonal communication, which can then influence both professional and social opportunities.

\section{Language Use}

Another way that disability is marginalized is through the use of language that is demeaning and oppressive (Tregoning, 2009a). In popular culture numerous terms that originated to describe some aspect of disability are frequently used to refer to stupidity consider the film title Dumb and Dumber, or exclamations like "That's so lame!" or "What a retard!" educators who encourage reconsideration of these commonly-used phrases are often greeted with the response that they are being overly sensitive or too concerned with political correctness (Tregoning), when their intent is to create welcoming and respectful learning and working environments. It is important for educators to examine the impact of phrases like "confined to ..." or "afflicted with ..." or "suffer from ..." to evoke pity when applied to disability, even if that was not the intent of the speaker (Evans \& Herriott, 2009). Similarly, the word "handicapped" connotes a beggar with cap in hand - the historic origin of the termwhich prompts emotive responses and inaccurate, stereotypical depictions of individuals with disabilities.

Educators are aware of the power of language, but often do not exercise the same care and intentionality in their language use surrounding disability that they would use when referring to race, ethnicity, religion, or sexual orientation. The American Psychological Association (2009) has recommended avoiding labels and "put[ting] the person first" (p. 72) - for example, "a student with a learning disability" rather "learning disabled student" - to emphasize that each individual has a complex array of social identities and is not defined by just one.

"Othering" language is also problematic. When contrasting two groups (e.g., students with and without disabilities, general education and special education classrooms), the use of terms like "regular" or "typical" or "normal" to identify the dominant group not only marginalizes everyone else, but also implies that the others are "irregular" or "atypical" or "abnormal"- the focus becomes deficiency rather than difference. 


\section{Disability in Diversity Courses: Student Perspective}

Although the number of college students with disabilities is growing and contributing to campus diversity in postsecondary education, many courses and texts that focus on diversity do not address disability Meanwhile, efforts to embed multiculturalism within mainstream courses and texts tend to focus on race, ethnicity, and gender, and generally exclude disability. One exception is "Exploring Diversity in the U.S. Through the Lens of Popular Culture", a freshman seminar offered at the University of Minnesota that meets a degree requirement in diversity in the U.S. For her capstone project for the course, co-author Rachel Katz chose to write a paper about mainstreaming children with autism (see pp. 2-3 of this paper). In their anonymous evaluations of the course, a number of students expressed their appreciation for the approach the course took to social identity, the inclusion of disability in the course content, and specifically the discussion about language use. The following paragraphs, authored by Rachel, address why this is important:

When people think of the term diversity, most think of race, religion, sexuality, and ethnicity. Society today teaches children, teenagers, and adults to not only accept, but embrace those who are different from themselves. Why is disability so often omitted from the realm of diversity? It is just as important to embrace individuals with disabilities as those of different races, religions, sexualities, and ethnicities. A large part of this acceptance is derived from a sense of comprehension. Integrating disability into courses about diversity would undoubtedly give a significant part of the population a deeper understanding of this aspect of social identity.

It is common knowledge that people tend to fear what they do not understand. Too many people are unaware of what the term disability means and what having a disability entails. For some, it is a matter of wearing hearing aids and/or being in a wheelchair, whereas others struggle with social interaction and/or communication. In order to overcome this innate fear, one must find a means in which to educate him or herself about the topic. What better way to obtain this knowledge than in a classroom? Many colleges and universities require students to take at least one course about diversity. If these courses included the vital issue of disability, it would give hundreds of thousands of students the opportunity to gain a better understanding of what disability is and why it is such an important societal issue today. Moreover, it would be encouraging acceptance and understanding of a diverse group of people.

It is widely understood that it is socially unacceptable to use racial, religious, and ethnic slurs, however many people seem to have no problem using the word "retard" or "retarded" in casual, every-day conversation. The words always have a negative connotation and are therefore automatically implying that those who are retarded are unintelligent or less-capable than others. This is a sweeping, incredibly unfair generalization that alienates a diverse group of individuals. Courses that address diversity deal with stereotyping and discrimination - disability very clearly fits into both of these categories. Therefore, courses about diversity could seamlessly integrate the topic of disability into the curriculum and, frankly, are doing society a disservice when they do not.

Those who have a deeper understanding of disability will be able to move past the fear of the unknown and truly accept and embrace individuals with physical and/or mental impairments. These educated individuals will have a broader view of diversity and will think twice about using offensive language such as "retard" and "retarded." Disability is and should be a key component in classes that address diversity.

\section{CONCLUSION}

Mainstreaming is a term commonly used in education in the U.S. to refer to inclusion for students with disabilities, up to a point. In the U.S., "separate", when used in reference to education, is understood to be "unequal", whether applied to race, disability, or any other aspect of social identity. However, in U.S. postsecondary institutions, despite the increasing number and proportion of students with disabilities and efforts on the part of a small but dedicated group of educators to implement universal design to ensure both physical and academic access, many of these students are still not fully integrated into college life. Providing accommodations for students with disabilities on an "as needed" basis may, in some instances, require separate facilities (e.g., for testing) or services (e.g., campus tours). However, in many situations, practices that identify, stigmatize, and segregate students with disabilities can be eliminated by rethinking how we can best educate all students. Few administrators, faculty members, and student development professionals are acquainted with universal design principles or models that adapt this architectural concept to education. Research on the outcomes of implementing UDL, UDI, and UID is needed. 
Strategically, there are other aspects of mainstreaming disability in higher education that must be reconsidered as well. Including disability in all conversations related to campus diversity, including hiring, mentoring, and the need for role models, would be an important first step. It is also imperative that disability be included in both specific courses on diversity and in efforts to integrate multicultural perspectives in all courses and curricular materials,

Finally, to accomplish these goals, educators must become more aware of their own attitudes toward disability and how the language they use when addressing disability reflects those attitudes. It is difficult to provide welcoming and respectful spaces for learning when administrators, faculty, and staff use "othering" language to describe students who are considered mainstream versus "the others" (i.e., everyone else). The underlying attitude conveyed by othering language is that students with disabilities are deficient rather than merely different.

\section{AUTHOR INFORMATION}

Jeanne L. Higbee is a professor in the Department of Postsecondary Teaching and Learning at the University of Minnesota. She is an ACPA-College Student Educators International Diamond Honoree and recipient of the ACPA Voice of Inclusion Medallion and Disability Ally Award, the College Reading and Learning Association Robert Griffin Award for Long and Outstanding Service, the Henry Young Award for Outstanding Individual Contribution to the National Association for Developmental Education, and NADE's Hunter R. Boylan Outstanding Research/Publication Award. Jeanne is the principal investigator for Pedagogy and Student Services for Institutional Transformation (PASS IT), funded by the U.S. Department of Education.

Rachel E. Katz is a sophomore from Eden Prairie, MN majoring in Elementary Education and Spanish at the University of Minnesota--Twin Cites. Upon graduation, her dream is to teach third grade at a Spanish immersion school in Minnesota, and she hopes to make immersion education more accessible to students with disabilities. Her interest in disability issues stems from spending time with her cousin, John, who has Autism. He inspired Rachel to further research the topic of mainstreaming and continues to inspire her in every aspect of her life.

Jennifer L. Schultz is an Assistant Professor and Curriculum Coordinator for Human Resource Management (HRM) in the College of Management at Metropolitan State University in Minneapolis, Minnesota. Her current research focuses on formal workplace social networks, classroom-based research on student attitudes and perceptions of pedagogy, and the application of multicultural teaching practices across the business curriculum.

\section{REFERENCES}

1. Alexandrin, J. R., Schreiber, I. L., \& Henry, E. (2008). Why not disclose? In J. L. Higbee \& E. Goff (Eds.), Pedagogy and student services for institutional transformation: Implementing universal design in higher education (pp. 377-392). Minneapolis: University of Minnesota, Center for Research on Developmental Education and Urban Literacy. Retrieved June 30, 2009, from http://www.cehd.umn.edu/passit/docs/PASSIT-Book.pdf

2. Antonio, A. L. (2001). The role of interracial interaction in the development of leadership skills and cultural knowledge and understanding. Research in Higher Education, 42, 593-617.

3. Barr, R. B., \& Tagg, J. (1995). From teaching to learning-A new paradigm for undergraduate education. Retrieved December 8, 2009, from http://ilte.ius.edu/pdf/BarrTagg.pdf

4. $\quad$ Barron, R., Pieper, J., Lee, T., Nantharath, P., Higbee, J. L., \& Schultz, J. (2007). Diversity and the postsecondary experience: Students give voice to their perspectives. In J. L. Higbee, D. B. Lundell, \& I. M. Duranczyk (Eds.), Diversity and the postsecondary experience (pp. 37-47). Minneapolis: University of Minnesota, Center for Research on Developmental Education and Urban Literacy. Retrieved June 30, 2009, from http://www.cehd.umn.edu/CRDEUL/docs/monograph/Diversity.pdf

5. Blimling, G. S. (2001). Diversity makes you smarter. Journal of College Student Development, 42, 517519.

6. Bowe, F. G. (2000). Universal Design in education-Teaching nontraditional students. Westport, CT: Bergin \& Garvey. 
7. Burgstahler, S., \& Cory, R. (Eds). (9009). Universal design of postsecondary education: From principles to practice. Cambridge, MA: Harvard Education Press.

8. Center for Applied Special Technology. (n.d.). UDL questions and answers. Retrieved November 29, 2007, from http://www.cast.org/research/faq/index.html

9. The Center for Universal Design. (1997). The principles of Universal Design (Version 2.0). Raleigh, NC: North Carolina State University. Retrieved December 11, 2006, from http://www.design.ncsu.edu/cud/about_ud/udprinciples.htm

10. The Center for Universal Design. (2007). About UD: Universal design history. Raleigh: North Carolina State University. Retrieved November 29, 2007, from http://www.design.ncsu.edu/cud/about_ud/udhistory.htm

11. Chickering, A. W., \& Gamson, Z. F. (1987). Seven principles for good practice in undergraduate education. AAHE Bulletin, 39(7), 3-7.

12. Crissman Ishler, J. L. (2005). Today’s first-year students. In M. L. Upcraft, J. N. Gardner, B. O. Barefoot, \& Associates, Challenging and supporting the first year-student: A handbook for improving the first year of college (pp. 15-26). San Francisco: Jossey-Bass.

13. David, M. E. (Ed.). (in press). Improving learning by widening participation in higher education. London, UK: Routledge/Taylor Francis Group.

14. Directgov. (n.d.). The Disability Discrimination Act. (n.d.). Retrieved April 23, 2009, from http://www.direct.gov.uk/en/DisabledPeople/RightsAndObligations/DisabilityRights/DG_4001068

15. Encarta ${ }^{\circledR}$ World English Dictionary [North American Edition]. 2009. Mainstreaming. Retrieved December 8, 2009, from http://encarta.msn.com/dictionary/mainstreaming.html

16. Evans, N. J. (2008). Theoretical foundations of universal instructional design. In J. L. Higbee \& E. Goff (Eds.), Pedagogy and student services for institutional transformation: Implementing universal design in higher education (pp. 11-23). Minneapolis: University of Minnesota, Center for Research on Developmental Education and Urban Literacy. Retrieved June 30, 2009, from http://www.cehd.umn.edu/passit/docs/PASS-IT-Book.pdf

17. Evans, N. J., \& Herriott, T. K. (2009). Philosophical and theoretical approaches to disability. In J. L. Higbee \& A. A. Mitchell (Eds.), Making good on the promise: Student affairs professionals with disabilities (pp. 27-40). Washington, DC: ACPA — College Student Educators International and University Press of America.

18. Facts about autism. (2009). New York: Autism Speaks. Retrieved December 8, 2009, from http://www.autismspeaks.org/whatisit/facts.php

19. Ferrier, F., \& Heagney, M. (Eds.). (2008). Higher education in diverse communities: Global perspectives, local initiatives. London, UK: European Access Network and Higher Education Authority of Ireland, in cooperation with Masaryk University Press.

20. Goff, E., \& Higbee, J. L. (2008a). Pedagogy and student services for institutional transformation (PASS IT) implementation guidebook for faculty and instructional staff. Minneapolis: University of Minnesota, Center for Research on Developmental Education and Urban Literacy. Retrieved June 30, 2009, from http://www.cehd.umn.edu/passit/docs/guidebook\%202.pdf

21. Goff, E., \& Higbee, J. L. (2008b). Pedagogy and student services for institutional transformation (PASS IT) implementation guidebook for student development and learning support. Minneapolis: University of Minnesota, Center for Research on Developmental Education and Urban Literacy. Retrieved June 30, 2009, from http://www.cehd.umn.edu/passit/docs/guidebook\%201.pdf

22. Gurin, P., Dey, E. L., Hurtado, S., \& Gurin, G. (2002). Diversity and higher education: Theory and impact on student outcomes. Harvard Educational Review, 72(3), 330-366.

23. Haas, D. (1993). Inclusion is happening in the classroom. Children Today, 22 (3).

24. Haas, D. (1997). Mainstreaming benefits all students. In B. Stalcup (Ed.), Current controversies: The disabled. San Diego, CA: Greenhaven Press.

25. Hatch, J. T., Ghere, D. L., \& Jirik, K. N. (2008). Empowering students with severe disabilities: A case study. In J. L. Higbee \& E. Goff (Eds.), Pedagogy and student services for institutional transformation: Implementing universal design in higher education (pp. 393-403). Minneapolis: University of Minnesota, Center for Research on Developmental Education and Urban Literacy. Retrieved June 30, 2009, from http://www.cehd.umn.edu/passit/docs/PASS-IT-Book.pdf 
26. Higbee, J. L. (2009). Student diversity. In R. Flippo \& D. Caverly (Eds.), Handbook of college reading and study strategies research ( $2^{\text {nd }}$ ed.; pp. 67-94). New York: Routledge, Taylor \& Francis Group.

27. Higbee, J. L., Chung, C. L., \& Hsu, L. (2004). Enhancing the inclusiveness of first-year courses through Universal Design. In I. M. Duranczyk, J. L. Higbee, \& D. B. Lundell (Eds.), Best practices for access and retention in higher education (pp. 13-26). Minneapolis: University of Minnesota, General College, Center for Research on Developmental Education and Urban Literacy. Retrieved September 15, 2007, from http://www.cehd.umn.edu/crdeul

28. Higbee, J. L., \& Goff, E. (2008). Pedagogy and student services for institutional transformation: Implementing universal design in higher education. Minneapolis: University of Minnesota, Center for Research on Developmental Education and Urban Literacy. Retrieved June 30, 2009, from http://www.cehd.umn.edu/passit/docs/PASS-IT-Book.pdf

29. Higbee, J. L., \& Kalivoda, K. S. (2008). The first-year experience. In J. L. Higbee \& E. Goff (Eds.), Pedagogy and student services for institutional transformation: Implementing universal design in higher education (pp. 245-253). Minneapolis: University of Minnesota, Center for Research on Developmental Education and Urban Literacy. Retrieved June 30, 2009, from http://www.cehd.umn.edu/passit/docs/PASSIT-Book.pdf

30. Higbee, J. L., \& Mitchell, A. A. (2009). Making good on the promise: Student affairs professionals with disabilities. Washington, DC: American College Personnel Association-College Student Educators International and University Press of America.

31. Hill, J. L. (1996). Speaking out: Perceptions of students with disabilities regarding the adequacy of services and willingness of faculty to make accommodations. Journal of Postsecondary Education and Disability, $12(1), 22-43$.

32. Horn, L., Nevill, S., \& Griffin, J. (2006). Profile of undergraduates in U.S. postsecondary education institutions: 2003-04 with a special analysis of community college students. Washington, DC: U.S. Department of Education, National Center for Education Statistics, Institute of Education Sciences. Retrieved September 14, 2007, from http://nces.ed.gov/pubs2006/2006184.pdf

33. Kalivoda, K. S. (2003). Creating access through Universal Instructional Design. In J. L. Higbee, D. B. Lundell, \& I. M. Duranczyk (Eds.), Multiculturalism in developmental education (pp. 25-34. Minneapolis: University of Minnesota, General College, Center for Research on Developmental Education and Urban Literacy. Retrieved September 15, 2007, from http://www.cehd.umn.edu/crdeul

34. Kalivoda, K. S., \& Higbee, J. L. (1998). Influencing faculty attitudes toward accommodating students with disabilities: A theoretical approach. The Learning Assistance Review, 3(2), 12-25.

35. Kalivoda, K. S., Higbee, J. L., \& Brenner, D. C. (1997). Teaching students with hearing impairments. Journal of Developmental Education, 20(3), 10-12, 14, 16.

36. Kalivoda, K. S., Totty, M. C., \& Higbee, J. L. (2009). Acces to information technology. In J. L. Higbee \& A. A. Mitchell (Eds.), Making good on the promise: Student affairs professionals with disabilities (pp. 226232). Washington, DC: American College Personnel Association-College Student Educators International and University Press of America.

37. Knox, D. K., Higbee, J. L., Kalivoda, K. S., \& Totty, M. C. (2000). Serving the diverse needs of students with disabilities through technology. Journal of College Reading and Learning, 30(2), 144-157.

38. Lee, C. M., \& Jackson, R. F. (1992). Faking it: A look into the mind of a creative learner. Portsmouth, NH: Boynton/Cook.

39. Maruyama, G., Nirebim, J. F., Gudeman, R. H., \& Marin, P. (2000). Does diversity make a difference? Three research studies on diversity in college classrooms. Washington, DC: American Council on Education \& American Association of University Professors.

40. McCune, P. (2001). What do disabilities have to do with diversity? About Campus, 6(2), 5-12.

41. Mesibov, G. B., \& Shea, V. (1996). Full inclusion and students with autism. Journal of Autism and Developmental Disorders, 26, 1-10.

42. Milem, J. F., \& Hakuta, K. (2000). The benefits of racial and ethnic diversity in higher education. Washington, DC: American Council on Education.

43. Pascarella, E. T., Palmer, B., Moye, M., \& Pierson, C. (2001). Do diversity experiences influence the development of critical thinking? Journal of College Student Development, 42, 257-271.

44. Rose, D. H. (2001). Universal design for learning: Deriving guiding principles from networks that learn. Journal of Special Education Technology, 16(2), 66-67. 
45. Rose, D. H., \& Meyer, A. (2000). Universal Design for Learning. Journal of Special Education Technology, 15(1), 67-70.

46. Scott, S. S., McGuire, J. M., \& Shaw, S. F. (2001). Principles of Universal Design for Instruction. Storrs, CT: University of Connecticut, Center on Postsecondary Education and Disability.

47. Scott, S. S., McGuire, J. M., \& Shaw, S. F. (2003). Universal Design for Instruction: A new paradigm for adult instruction in postsecondary education. Remedial and Special Education, 24(6), 369-379.

48. Silver, P., Bourke, A., \& Strehorn, K. C. (1998). Universal Instructional Design in higher education: An approach for inclusion. Equity and Excellence in Education, 31(2), 47-51.

49. Smith, D. G., \& Schonfeld, N. B. (2000). The benefits of diversity: What the research tells us. About Campus, 5(5), 16-23.

50. Terenzini, P. T., Cabrera, A. F., Colbeck, C. L., Bjorklund, S. A., \& Parent, J. M. (2001). Racial and ethnic diversity in the classroom: Does it promote student learning? Journal of Higher Education, 72, 509-531.

51. Tregoning, M. E. (2009a). Being an ally in language use. In J. L. Higbee \& A. A. Mitchell (Eds.), Making good on the promise: Student affairs professionals with disabilities (pp. 173-176). Washington, DC:

American College Personnel Association-College Student Educators International and University Press of America.

52. Tregoning, M. E. (2009b). "Getting it" as an ally: Interpersonal relationships between colleagues with and without disabilities. In J. L. Higbee \& A. A. Mitchell (Eds.), Making good on the promise: Student affairs professionals with disabilities (pp. 183-186). Washington, DC: American College Personnel AssociationCollege Student Educators International and University Press of America.

53. Williams, W. M., \& Ceci, S. J. (1999, August 6). Accommodating learning disabilities can bestow unfair advantages. The Chronicle of Higher Education, B4-B5.

54. Wisbey, M. E., \& Kalivoda, K. S. (2008). Residential living for all: Fully accessible and "liveable.” In J. L. Higbee \& E. Goff (Eds.), Pedagogy and student services for institutional transformation: Implementing universal design in higher education (pp. 255-266). Minneapolis: University of Minnesota, Center for Research on Developmental Education and Urban Literacy. Retrieved June 30, 2009, from http://www.cehd.umn.edu/passit/docs/PASS-IT-Book.pdf

55. Uncertain welcome [video]. (2002). Minneapolis: University of Minnesota, General College and Disability Services. Retrieved December 9, 2009, from http://www.cehd.umn.edu/passit/videos.html

56. UN Enable (n.d.). Rights and dignity of persons with disabilities. Retrieved April 23, 2009, from http://www.un.org/disabilities/

57. U.S. Department of Commerce, Bureau of the Census. (1997). Census brief: Disabilities affect one-fifth of all Americans. Washington, DC: Author. Retrieved August 16, 2009 from http://www.census.gov/prod/3/97pubs/cenbr975.pdf

58. U. S. Department of Justice (n.d.). Americans With Disabilities Act, as amended. Retrieved September 12, 2009 from http://www.ada.gov/pubs/ada.htm

59. Zuñiga, X. (2003). Bridging differences through dialogue. About Campus, 7(6), 8-16. 